\title{
Educational level, socio-economic status and relationship with quality of life in elderly residents of the city of Porto Alegre/RS, Brazil
}

\author{
Christiane de Fátima Colet*, Paulo Mayorga, Tânia Alves Amador
}

Medicine Production and Control Department, Pharmacy College, Federal University of Rio Grande do Sul

\begin{abstract}
The objective of this study was to verify the index of quality of life of elderly individuals belonging to groups, from different socioeconomic strata in the city of Porto Alegre, Rio Grande do Sul State. The research adopted a transversal model, used to collect data from the SF-36 questionnaire. The sampling is the intentional type and comprised: 61 elderly people in Class A, 80 in Class C, and 84 in Class E. The research was approved by the Committee of Ethics in Research/UFRGS. In relation to the quality of life, Class A presented higher scores than did Classes C and E on the pain, vitality, social aspect and mental health areas. The results also showed a significant difference in quality of life among university educated individuals versus the other schooling groups, on the pain, vitality, mental health and social aspect fields. Quality of life is a complex concept to study, but essential to improve the perception of health and welfare by the elderly.
\end{abstract}

Uniterms: Elderly/quality of life. Elderly/health.

\begin{abstract}
O objetivo deste trabalho foi verificar o índice de qualidade de vida de idosos participantes de grupos de convivência, de diferentes estratos socioeconômicos do município de Porto Alegre/RS. A pesquisa seguiu um modelo de estudo transversal e utilizou para coleta de dados o questionário SF-36. A amostragem foi do tipo intencional e foi composta por: 61 idosos na classe A, 80 na classe C e de 84 na classe E. A pesquisa foi aprovada pelo Comitê de Ética em Pesquisa da UFRGS. Em relação à qualidade de vida, a classe A apresentou escores melhores que a classe $\mathrm{C}$ e $\mathrm{E}$ nos domínios dor, vitalidade, aspecto social e saúde mental. Houve diferença significativa de qualidade de vida no ensino superior completo, em relação aos demais estratos de escolaridade, nos domínios dor, vitalidade, saúde mental e aspecto social. A qualidade de vida é um conceito complexo de ser estudado, mas essencial para que haja melhora na percepção de saúde e do bem-estar pelos idosos.
\end{abstract}

Unitermos: Idosos/qualidade de vida. Idosos/saúde.

\section{INTRODUCTION}

The traditional measures of health outcome based on laboratory examinations and clinical evaluation are of undeniable importance. However, they evaluate the illness more than the sick person and alone are insufficient to measure outcomes in Chronic Diseases, when the objective of the treatment is not the cure, but the reduction of the disease impact in different area of a patient's life (Fleck,

\footnotetext{
*Correspondence: C. F. Colet. Departamento de Produção e Controle de Medicamentos, Faculdade de Farmácia, Universidade Federal do Rio Grande do Sul. Avenida Ipiranga, 2752, Santana - 90610000 - Porto Alegre - RS, Brasil. E-mail: chriscolet@yahoo.com.br
}

2008). However, although a consensus exists on the importance of quality of life evaluation, its definition remains controversial. Some authors recognize the complexity and the impossibility of properly conceptualizing quality of life, treating it like an emergent variable (Gladis, Gosch, Dishuk, 1999).

According to the World Health Organization (WHO), quality of life in its broader sense is characterized as an individual perception on one's position in life, the culture and value systems in context of life, and in relation to their objectives, expectations, standards and concerns. Therefore, the quality of life concept belongs in a polysemous semantic field, with one facet related to the way of 
life, its conditions and style while another encompasses ideas about sustainable development and human and social rights (Carr et al., 2003; Minayo, 2003).

Moreover, quality of life is a multidimensional concept that covers several areas, motivations and social indicators, such as functional position (activities of self care, mobility, physical activities and performance of roles), disease and symptoms related to the treatment, social functioning (social activities and relationships), mental health (mood, self- esteem, well-being perception), spiritual and existential development, cultural values, environment security (suitable residence, economic inco$\mathrm{me})$, love, freedom, happiness, satisfaction, among others (Minayo, 2003).

The introduction of the quality of life concept was an important contribution for the health measures of outcome. Given its comprehensive nature and close link to an individual's feeling and perceptions, it has an intrinsic and intuitive value. It is closely related to one of the basic desires of humankind, which is to live well and feel good (Fleck, 2008). Thus, quality of life emerged as an indicator of the effectiveness and impact of certain treatments, the comparison between procedures for the control of health problems, of the physical and psychosocial impact of diseases, knowledge production associated to the integration efforts and also of the interchange between professionals and researchers about the subject (Seidl, Zannon, 2004).

The questionnaire used to assess quality of life is the Medical Outcomes Study Short Form-36 Healthy Survey (SF-36), which was developed in the 1980s in the U.S.A., and can be applied in different situations while offering good sensitivity resolving the distribution problem by eliminating the extreme scale - good and bad. Unlike other instruments, the SF-36 does not assess such areas as sleep, social relationships, sexual function, dependence, self image perception and future perception (Carr et al., 2003). In Brazil, the SF-36 was translated and validated to assess quality of life in patients with rheumatoid arthritis. Due to adaptation to cultural and socioeconomic conditions of the Brazilian population, as well as to its reproducibility, it is a useful parameter for assessing quality of life (Fleck, 2008).

While there is a consensus that assessment of quality of life in elderly people is based on a multidimensional perception, and does not entail simply specifying the areas and the criteria defining good quality of life in this age group, because there are different aging patterns (Fleck, 2008).

We previously published part of the results of this research relating to the use of medicines by elderly participants belonging to groups in Porto Alegre, stratified by socioeconomic class (Colet, Mayorga, Amador, 2008). The aim of this article was to present the related results on the quality of life in different groups of elderly people and compare them to other aspects surveyed, such as educational level and use of medicines.

\section{METHODS}

The study adopted a transversal model, and used a structured questionnaire as the data collection instrument, applied between March and July of 2007.

The study population comprised elderly participants of companionship groups, these being social spaces that enable aged citizens older than 60 years of age to participate in community activities, allowing them to strengthen social relationship and practice a range of activities.

The sampling was intentional, selecting individuals aged 60 years or older, residents in the city of Porto Alegre, Rio Grande do Sul State, that belonged to companionship groups. Two selected groups consisting of a population with the socioeconomic Class A; two groups with socioeconomic Class $\mathrm{C}$ and two with socioeconomic class $\mathrm{E}$. Exclusion criteria were being less than sixty years of age and/or presenting with cognitive problems.

A pilot study was initially carried out to test the questionnaire. The SF-36, was developed to assess quality of life (translated and validated in Brazil in 1997) (Ciconelli et al., 1999) and was applied to the interviewee.

The SF-36 version 1.0 is a short form questionnaire with 36 items that measure eight health-related quality of life domains: physical functioning (PF), social functioning (SF), role limitation due to physical problems (RP), role limitation due to emotional problems (RE), mental health (MH), energy and vitality (VT), bodily pain (BP), and general perception of health (GH). The SF-36 also includes an item to assess changes in respondent's health status during the past year. For each quality of life domain tested, item scores were coded, summed, and transformed into a scale ranging from 0 (worst) to 100 (best) using the standard SF-36 scoring algorithms (Osaki, Belford, 2004).

The questionnaire was tested with the intention of being self-applied by the interviewees. However, considering that part of the population in Brazil received only primary school education or were illiterate (IBGE, 2001), it was decided that the interviewer should apply the questionnaire to all interviewees. Furthermore, it was observed during the pilot study, some words proved difficult to understand by the elderly, especially among those with low education. Nevertheless, because it is a previously validated questionnaire, it was preferable to keep it in its original format and be wary of possible questions for interviews and where necessary provide further clarification.

Our group previously published data on medicines 
used by these groups of people (Colet, Mayorga, Amador, 2008), for which interviewees answered another questionnaire with specific questions about the topic requiring respondent reporting of the drugs, prescriptions, inserts and/or packaging the products used. To investigate the association between quality of life for eight domains and the number of medicines used by interviewees, data were compared using the correlation coefficient test.

The statistics analysis was performed using Software SPSS, version 13. The Analysis of Variance (ANOVA) and Tukey's test was used to analysis the results of quality of life in eight domains and the socioeconomic status, quality of life and schooling. The $\mathrm{T}$ test for independent samples was used to verify association between sex and quality of life. The correlation coefficient test was used to verify the association between quality of life and age, interviewee income and family income.

The study was approved by the Committee of Ethics in Research of the University Federal do Rio Grande do Sul.

\section{RESULTS AND DISCUSSION}

Table I show the values, stratified into social classes, the SF-36's eight domains of the elderly quality of life interview. In Class A, the minimum value was obtained in energy and vitality (67.37), and this domain also showed the lowest value in Classes $\mathrm{C}$ and $\mathrm{E}$, with rates of 53.12 and 52.38 , respectively. The maximum score in Class A was 89.45 , related to social functioning. In Class $\mathrm{C}$ the highest score was obtained on the item related to general perception of health, whereas role limitation due to emotional problems showed the highest value in Class E. The domain of physical functioning, which is diminished in the elderly due to physiological characteristics of this age group, had values of 74.83 in Class A, 69.62 in Class C and 67.38 in Class E. These scores are higher than those found in a population survey of quality of life in older adults, where this may be related to the participation of the interviewer in the companionship groups (Camarano, 2004).

There was a statistically significant difference (ANOVA / Tukey's) between Class A to Class C and E, on Bodily Pain $(\mathrm{F}=7.14, \mathrm{p}<0.001)$, Energy and vitality $(\mathrm{F}=23.16, \mathrm{p}<0.001)$, Social Functioning $(\mathrm{F}=13.21$, $\mathrm{p}<0.001)$, and Mental health $(\mathrm{F}=19.19, \mathrm{p}<0.001)$. In other domains, no statistically significant difference was found between the classes studied $(p<0.05)$. The domains studied by the SF-36 are divided into physical and mental health. Physical health are included in the domains: Physical functioning, Role limitation due to physical problems, Bodily Pain and General Perception of Health, while mental health encompasses the domains Energy \& Vitality, Role limitation due to emotional problems, Social Functioning and Mental health (Osaka, Belford, 2004). Therefore, it is evident that Class A had the highest scores on the Mental health area and on one domain of the Physical health area.

Although the older Class A had statistically higher scores related to bodily pain, the mean number of diseases affecting this group was found to be similar to that of the other social classes studied. This may be related to the fact that quality of life is a subjective concept and the definition of pain considers the existence of several components, mainly nociception (pain sensation) and emotional reactivity. Moreover, these factors may be associated with other variables, such as depression state, loneliness and socioeconomic factors (Fleck, 2008; Loeser, Melzack, 1999).

Energy and vitality was another domain on which Class A scored higher and this could be related to tired-

TABLE I - Mean ( $($ SD) quality of life scores (SF-36) in elderly companionship groups. Porto Alegre/RS, 2007

\begin{tabular}{lccc}
\hline Domains & $\begin{array}{c}\text { Class A }(\mathbf{n}=\mathbf{6 1}) \\
\text { Mean } \pm \text { SD }\end{array}$ & $\begin{array}{c}\text { Class C }(\mathbf{n}=\mathbf{8 0}) \\
\text { Mean } \pm \text { SD }\end{array}$ & $\begin{array}{c}\text { Class E }(\mathbf{n}=\mathbf{8 4}) \\
\text { Mean } \pm \text { SD }\end{array}$ \\
\hline PF & $74.83 \pm 25.15$ & $69.62 \pm 33.41$ & $67.38 \pm 32.00$ \\
RP & $75.00 \pm 41.26$ & $78.43 \pm 39.33$ & $74.11 \pm 42.06$ \\
BP & $79.44 \pm 21.02^{*}$ & $63.36 \pm 31.71$ & $61.51 \pm 33.08$ \\
GH & $80.89 \pm 16.05$ & $78.90 \pm 22.65$ & $74.10 \pm 27.12$ \\
VT & $67.37 \pm 11.68^{*}$ & $53.12 \pm 14.81$ & $52.38 \pm 15.11$ \\
RE & $71.79 \pm 38.08$ & $72.52 \pm 43.34$ & $75.00 \pm 41.04$ \\
SF & $89.45 \pm 20.39^{*}$ & $72.12 \pm 31.59$ & $67.33 \pm 24.09$ \\
MH & $81.08 \pm 17.14^{*}$ & $63.90 \pm 25.40$ & $58.12 \pm 22.16$ \\
\hline
\end{tabular}

$\mathrm{n}=$ total number interviewed; $\mathrm{SD}=$ Standard Deviation; ${ }^{*} \mathrm{p}<0.05$, Analysis of Variance (ANOVA) and Tukey’s test; PF $=$ Physical functioning; $\mathrm{RP}=$ Role limitation due to physical problems; $\mathrm{BP}=\mathrm{Bodily}$ Pain; $\mathrm{GH}=$ General Perception of Health; VT= Energy $\&$ Vitality; RE= Role limitation due to emotional problems; $\mathrm{SF}=$ Social Functioning; $\mathrm{MH}=$ Mental Health 
ness in performing daily activities. The scores for Social Functioning, which were also shown to be higher in Class A, may be related to physical or emotional problems that may have interfered in social interaction with family and friends. It was also observed that the elderly in Class A were included in many activities of entertainment and living with a smaller number of people. In relation to mental health, this could be related to the elderly feeling calm, discouraged and nervous. Class A also showed a higher index than the other study classes. But it was noted that the profile of use of medicines indicated for central nervous system, particularly antidepressants and anxiolytics, was similar to that of the other social classes studied.

This study found that elderly people with higher income (Class A) had a better quality of life, scoring significantly higher on four out of the eight domains assessed by the questionnaire. According to Fleck and collaborators (2008), levels of income and education, good living conditions and health, a good network of friends, the maintenance of good family relationships are all factors that can contribute to quality of life and subjective welfare, in the sense of selfefficacy, and thus for overall functioning of the elderly.

Physical functioning scores in this study ranged from between 65 and 75, and this domain generally shows lower values in elderly than in other age groups due to the physiological characteristics of elderly. In a study by Pimenta and collaborators (2008), the result obtained by the elderly on this domain was 61.1. The lower functional capacity of the elderly compared to other age strata is associated with several variables such as morbidity, presence of cardiovascular disease, low level of education, female sex, overweight, smoking, sedentarianism, non-white race (Ferraro, Farmer, Wybraniec, 1997). One reason that can be raised to explain the higher scores in our study compared to others found in the literature relates to fact that the elderly in the present study were socially active (Camarano, 2004).

Data on quality of life were stratified according to sex of the interviewee and there was no statistically significant difference $(\mathrm{p}<0.05, \mathrm{t}$ test for independent samples) between the sexes on any of the SF-36 domains. Although this study observed no significant difference between the sex of respondents and the domains examined by the SF-36, it should be noted that this study sample was predominantly female, preventing any inferences from being made. The literature indicates that older males present, except for domains of General Perception of Health and Emotional functioning, higher scores across all other domains assessed by the questionnaire for quality of life. This can be correlated to a female tendency to consider their health worse compared to men of the same age and therefore report lower quality of life (Mcdonough, Walters,

\section{1; Kubzansky et al., 1998).}

To verify if the number of medicines reported by interviewees affected quality of life, the correlation coefficient test was applied to cross the data collected through another questionnaire (data published in Colet, Mayorga and Amador, 2008) and noted that no significant relationship ( $p>0.05)$ was found between the number of medicines used by older people and the domains measured by the SF-36. In the literature, retirees who do not regularly use medicines have a significant tendency for increased scores on functional capacity (Gama et al., 2000). The maintenance of functional capacity is directly linked to quality of life, since it refers to the ability of an individual to remain in the community with independence (Rosa, Benício, Latorre, 2003). Fleck and collaborators (2008) showed that the use of medicines was indicated by the elderly as a factor that can worsen quality of life by decreasing their autonomy, but can be positive owing to the effect that some medicines can provide.

Table II shows the data, stratified according to level of education, on interviewee quality of life. Notably, there is a significant difference ( $\mathrm{p}<0.05$, ANOVA / Tukey) for higher education, in relation to other levels of education, on the bodily pain $(\mathrm{F}=3.71, \mathrm{p}<0.05)$ and energy and vitality $(\mathrm{F}=9.23, \mathrm{p}<0.001)$ domains. In mental health $(\mathrm{F}=7.00, \mathrm{p}<0.001)$ and Social Functioning $(\mathrm{F}=8.98$, $\mathrm{p}<0.001)$ domains, there was a significant difference ( $p<0.05$, ANOVA/Tukey's) in high school and secondary school education in relation to other levels of education.

The level of education confers several advantages for health, such as influences of psychosocial factors and behavior. Individuals with a higher educational level are less likely to be exposed to risk factors for diseases and to be submitted to inadequate working conditions. Lower level education promotes access to information, the modification of lifestyle, to adopt healthy habits, the demand for health services, to engage in activities that prioritize health promotion, and especially to follow correct guidelines related to achieving a better quality of life (Ross, Wu, 1996).

The SF-36 contains a question pertaining to selfrated health reported by interviewees. The results were classified as excellent, good or bad (Table III). In all social classes studied, there was a predominance of elderly people who considered their health as "good" (at 68\%, 74\% and $68 \%$ in class A, C and E, respectively). In Class A, $30 \%$ of respondents considered their health as excellent, whereas in other social classes a large number of elderly people consider their health as bad, with percentages of $20 \%$ and $31 \%$ for Class C and E, respectively.

According to the literature, self-reported health status can be influenced by the following factors: demo- 
TABLE II - Mean ( \pm SD) scores of quality of life (SF-36), stratified by education level, of participants in companionship groups, Porto Alegre/RS

\begin{tabular}{lcccc}
\hline Domain & $\begin{array}{c}\text { IPS }(\mathbf{n}=\mathbf{1 0 9}) \\
\text { Mean } \pm \text { SD }\end{array}$ & $\begin{array}{c}\text { PS(n=40) } \\
\text { Mean } \pm \text { SD }\end{array}$ & $\begin{array}{c}\text { SS (n=38) } \\
\text { Mean } \pm \text { SD }\end{array}$ & $\begin{array}{c}\text { HS (n=38) } \\
\text { Mean } \pm \text { SD }\end{array}$ \\
\hline PF & $66.43 \pm 31.91$ & $71.84 \pm 35.55$ & $71.50 \pm 28.22$ & $79.86 \pm 21.22$ \\
RP & $76.62 \pm 40.62$ & $77.63 \pm 41.01$ & $75.00 \pm 40.03$ & $75.00 \pm 41.83$ \\
BP & $62.50 \pm 32.37$ & $64.76 \pm 33.19$ & $66.80 \pm 25.73$ & $81.63 \pm 23.09 *$ \\
GH & $72.98 \pm 27.91$ & $81.36 \pm 17.42$ & $84.12 \pm 13.59$ & $80.52 \pm 18.26$ \\
VT & $53.19 \pm 15.92$ & $52.36 \pm 13.44$ & $60.87 \pm 13.34$ & $66.25 \pm 13.69 *$ \\
RE & $73.14 \pm 42.62$ & $71.94 \pm 44.19$ & $75.00 \pm 38.33$ & $72.30 \pm 36.94$ \\
SF & $68.13 \pm 27.88$ & $68.55 \pm 30.84$ & $86.25 \pm 23.10 *$ & $74.85 \pm 27.59 *$ \\
MH & $60.79 \pm 24.06$ & $62.21 \pm 24.13$ & $73.30 \pm 21.32 *$ & $78.44 \pm 20.46^{*}$ \\
\hline
\end{tabular}

$\mathrm{n}=$ total number interviewed; $* \mathrm{p}<0.05$, Analysis of Variance (ANOVA) and Tukey's test; $\mathrm{PF}=\mathrm{Physical}$ functioning; RP= Role limitation due to physical problems; $\mathrm{BP}=$ Bodily Pain; $\mathrm{GH}=$ General Perception of Health; VT= Energy Vitality; RE= Role limitation due to emotional problems; $\mathrm{SF}=$ Social Functioning; $\mathrm{MH}=$ Mental Health; IPS = incomplete primary school; PS = primary school; $\mathrm{SS}=$ secondary school; HS= high school.

TABLE III - Self-reported health status of elderly population interviewed. Porto Alegre/Rio Grande do Sul State, 2007

\begin{tabular}{lcccccc}
\hline Social Class & \multicolumn{2}{c}{ Excellent } & \multicolumn{1}{c}{ Good } & \multicolumn{2}{c}{ Bad } \\
\cline { 2 - 7 } & $\mathbf{N}$ & $\mathbf{\%}$ & $\mathbf{n}$ & $\mathbf{\%}$ & $\mathbf{N}$ & $\mathbf{\%}$ \\
\hline CLASS A (n=61) & 18 & 30 & 42 & 68 & 1 & 2 \\
CLASS C (n=80) & 5 & 6 & 59 & 74 & 16 & 20 \\
CLASS E (n=84) & 1 & 1 & 57 & 68 & 26 & 31 \\
\hline
\end{tabular}

graphic (age, sex, marital status and family arrangements), socioeconomic (education and individual and family income), presence of chronic diseases, functional capacity and mobility (Lima-Costa, Firmo, Uchoa, 2004). Thus, the fact that Class A presents a better self-reported state of health may be related to higher income and education and improved quality of life in older people of this class.

A study in Veranópolis, Rio Grande do Sul, in 219 elderly people aged over eighty years considered high income an indicator for the classification of health into good or bad (Xavier et al., 2003). Perceived morbidity may be lower among lower social strata, which may be related, among other things, to differences in values assigned to health among the interviewee with lower and higher income. Low income, independent of the availability of adequate health care, acts on individuals in a negative way regarding the adoption of healthy behavior at home and access to services and material resources required for health care. There are reports that among the elderly from lower social classes, fewer choose to use the health services, more have low adherence to treatment and have little access to medicines, as shown by Lima-Costa and collaborators (2003).

\section{CONCLUSIONS}

Despite the availability of other specific questionnaires for measuring quality of life in the elderly, the literature has shown the SF-36 to be suitable for evaluation in this age stratum (Fleck, 2008; Pimenta et al., 2008). However, some limitations were found when applied to the elderly, such as the item related to physical characteristics, which are limitations imposed by old age itself, on how to walk many miles, carry weight etc.. Another restriction relates to the difficulties of understanding certain issues, especially by elderly with low educational level. Moreover, quality of life is subjective, and two measurements invariably result in different answers, since each assessment reflects an individual experience that can be limited by the particular environment of the individual or by the specific time (Fleck, 2008).

In health, to rethink the quality of life is essential and is based on the argument that better health contributes to improved quality of life or well-being while the opposite is also true whereby an improvement in quality of life results in improved health. 


\section{REFERENCES}

CAMARANO, A.A. Os novos idosos brasileiros: muito além dos 60? Rio de Janeiro: IPEA, 2004. 594 p.

CARR, D; HOUSE, J.S.; KESSLER, R.C.; NESSE, R.M.; SONNEGA, J.; WORTMAN, C. Marital quality and psychological adjustment to widowhood among older adults: a longitudinal analysis. Crit. Care Clin., v.19, n.4, p.729-748, 2003.

CICONELLI, R.M.; FERRAZ, M.B.; SANTOS, W.; MEINÃO, I.; QUARESMA, M.R. Tradução para a língua portuguesa e validação do questionário genérico de avaliação de qualidade de vida SF-36 (Brasil SF-36). Rev. Bras. Reumatol., v.39, n.3, p.143-150, 1999.

COLET, C.F.; MAYORGA, P.; AMADOR, T.A. Utilização de medicamentos por idosos inseridos em grupos de convivência do município de Porto Alegre/RS/Brasil. Lat. Am. J. Pharm., v.27, n.3, p.460-467, 2008.

FERRARO, K.F.; FARMER, M.M.; WYBRANIEC, J.A. Health Trajectories: Long-term Dynamics Among Black and White Adults. J. Health Soc. Behav., v.38, n.1, p.38-54, 1997.

FLECK, M.P.A. A avaliação de qualidade de vida: guia para profissionais da saúde. Porto Alegre: Artmed; 2008. 228 p.

GAMA, E.V.; DAMIAN, J.; DEL MOLINO, J.P.; LOPEZ, M.R.; PEREZ, M.L.; IGLESIAS, F.J.G. Association of individual activities of daily living with self rated health in older people. Age ageing, v.29, n.3, p.267-2670, 2000.

GLADIS, M.M.; GOSCH, E.A.; DISHUK, N.M. Quality of life: expanding the scope of clinical significance. J. Clin. Psychol., v.67, n.3, p.320-331, 1999.

INSTITUTO BRASILEIRO DE GEOGRAFIA E ESTATÍSTICA. IBGE. Censo Demográfico, 2000. Rio de Janeiro: IBGE, 2001. Available at: <http://www.ibge.gov. br.>. Accessed on: 02 fev. 2007.

KUBZANSKY, L.D.; BERKMAN, L.F.; GLASS, T.A.; SEEMAN, T.E. Is educational attainment associated with shared determinants of health in the elderly? Findings from the MacArthur studies of successful aging. Psycho. Med., v.60, n.5, p.578-585, 1998.
LOESER, J.D.; MELZACK, R. Pain: an overview. Lancet, v.353, n.9164, p.1607-1609, 1999.

LIMA-COSTA, M.F.; BARRETO, S.M.; GIATTI, L.; UCHOA, E. Desigualdade social e saúde entre idosos brasileiros: um estudo baseado na Pesquisa Nacional por Amostra de Domicílios. Cad. Saúde Pública, v.19, n.3, p.745-757, 2003.

LIMA-COSTA, M.F.; FIRMO, J.O.A.; UCHOA, E. A estrutura da autoavaliação da saúde entre idosos: Projeto Bambuí. Rev. Saúde Pública; v.38, n.6, p.827-834, 2004.

MCDONOUGH, P.; WALTERS, V. Gender and health: reassessing patterns and explanations. Soc. Sci. Med., v.52, n.4, p.547-559, 2001.

MINAYO, M.C.S. Violence against the elderly: the relevance of an old health problem. Cad. Saúde Pública, v.19, n.3, p.783-789, 2003.

OSAKI, M.H.; BELFORD, R. Qualidade de vida e custos diretos com blefaroespasmo essencial e espasmo hemifacial, tratados com toxina butulinica-A. Arq. Bras. Oftalmol., v.67, n.1, p.43-49, 2004.

PIMENTA, F.A.P.; SIMIL, F.F.; TÔRRES, H.O.G.; AMARAL, C.F.S.; REZENDE, C.F.; COELHO, T.O. Avaliação da qualidade de vida de aposentados com a utilização do questionário SF-36. Rev. Assoc. Med. Bras., v.54, n.1, p.55-60, 2008.

ROSA, T.E.; BENICIO, M.H.; LATORRE, M.R. Fatores determinantes da capacidade funcional entre os idosos. Rev. Saúde Pública, v.37, n.1, p.40-48, 2003.

ROSS, C.E.; WU, C.L. Education, age, and the cumulative advantage in health. J. Health Soc. Behav., v.37, n.1, p.104120, 1996.

SEIDL, E.M.F.; ZANNON, C.M.L.C. Qualidade de vida e saúde: aspectos conceituais e metodológicos. Cad. Saúde Pública, v.20, n.2, p.580-588, 2004.

XAVIER, F.M.F; FERRAZ, M.P.T.; MARC, N.; ESCOSTEGUY, N.U.; MORIGUCHI, E. A definição dos idosos de qualidade de vida. Rev. Bras. Psiquiatr., v.25, n.1, p.31-39, 2003.

Received for publication on $17^{\text {th }}$ September 2009. Accepted for publication on $01^{\text {st }}$ July 2010. 